\title{
"'tis by Comparison we can Judge and Chuse [sic!]": Incomparable Oroonoko
}

Monika Class

\section{Introduction}

Aphra Behn's Oroonoko, or The Royal Slave, a True History was first published in early summer of 1688 less than a year before the author's death. The novel narrates the short life of a royal West African general. It delineates how it comes about that this prince, who starts his military career successfully defending his kingdom at the age of seventeen, who undergoes experiences of forbidden love, kidnapping, and enslavement, and who leads a slave rebellion that fails, ends up dismembered in the British colony of Surinam. The British had colonized the territory in 1652, but the Dutch usurped the colony in 1667 (Hughes 2007: xxxi). Aphra Behn probably resided on a Surinamese sugar plantation in the early 1660s, but there is no extant trace of the enslaved figure whose free name was Oroonoko and slave name Caesar; nor is there documentary evidence of a slave rebellion on a British Surinamese plantation at the time (Britland 2019).

Since the mid-1980s, Oroonoko has been elevated to the status of a canonical work of English prose fiction (Aravamudan 2014: 27). Some scholars have designated Oroonoko the origin of the English novel and the first American novel as well (Azim 1993: 35; Doyle 2008: 97; Spengemann 1984; Schabert 1997: 305). While the scholarship on Oroonoko is vast, the ideology of the novel is particularly contested partly because the ambiguous configuration of the text - a dialogization of multiple discursive practices - resists a translation into stable ideologies (Athey and Alarcón 1993: 417). Central to this body of scholarship is the question to what extent Oroonoko's struggles work as a surrogate for late seventeenth-century and early eighteenth-century dominant British historiography. This focus can be traced back to Laura Brown and Felicity Nussbaum's The New Eighteenth Century (1987). Building on New Histori- 
cism, the edited volume played an important role in the integration of gender, race, class and empire studies into (American) eighteenth-century scholarship (Alkon 1989: 581). In her essay, Laura Brown influentially established the reading that the figure of Oroonoko alias Caesar stands in for the Stuart monarchs and by extension for Behn's allegiance with them. ${ }^{1}$ Accordingly, Anglocentric Restoration politics have served as the major tertium comparationis for analyses of Behn's powerful work of literature. Commentators disagree about the colonial significance of Oroonoko: Some scholars regard the narrative as an endorsement of plantation slavery (e.g. Moira Ferguson 1992: 356), others as a denouncement (e.g. Goreau 1980: 289) and many address the intrinsic ambivalences about colonial power, the slave trade, race and gender within the text (Griffin 2019: 107; Lipking 2004: 175; Morrissey 2016: 11; Margaret Ferguson 1991: 159; Hughes 2002: 1).

In light of these developments in eighteenth-century studies, the present essay contributes to the investigation of the practices of comparing in long eighteenth-century Britain by examining the comparisons and the rhetorical suspension of comparability in the narrative configuration of Behn's Oroonoko. In the preface, dedicated to the Scottish nobleman Richard Maitland, Behn draws attention to the importance of comparison for the "Critical Reader" (Oroonoko, 1995: 56): "tis by Comparison we can Judge and Chuse [sic!]" (55). At the same time, however, Behn configured reversals of the eponymous hero's fate in ways that complicate and postpone comparability. Scholars have noted that analogies between Behn's text and British historiography of the period include inconsistencies. They observe, for instance, that this "hybrid masterpiece" (Botelho 2014: 34) contains "contradictory" combinations of rhetorical patterns (Chibka 1998: 513).

In this spirit, this essay follows a hermeneutic-phenomenological approach by analysing the operations of comparability and incomparability within the emplotment based on Paul Ricoeur's theory of triple mimesis (Ricoeur 1984). Broadly speaking, the approach means that readerly embodiment plays a vital role in the signification process that results from the encounter of readers with the text (Ricoeur 1988). Not only is meaning constituted through the intellectual fusion of horizons (Gadamer 1989), the

According to Sal Nicolazzo, the collection has had the adverse effect of priming "eighteenth-century scholarship to understand race and empire primarily as topics that politicized enquiry might peruse, rather than as foundational material structures that implicate us and our work in objects of study" (Nicolazzo 2020: 233). 
signification of fiction also depends on readers' emotions and affects according to Ricoeur (1988: 137). Author's compositions play an important role in such embodied reading experiences. Ricoeur theorizes such representations under the heading "emplotment".

The term "emplotment" designates "the operation that draws configuration out of a simple succession" (Ricoeur 1984: 65). Emplotment (mise en intrigue) creates narratives by lending a mere sequence of events a coherent form that encompasses a beginning, a middle and an end. The entire level of configuration within Ricoeur's mimetic model consists of this narrative operation (i.e., emplotment). Besides configuration, there exist two further levels in the mimetic process, namely prefiguration and refiguration. Configuration, which is synonymous with narrative composition, is the middle part of the model, preceded by the prefiguration and followed by refiguration. Ricoeur bases emplotment on the Aristotelian notion of "muthos", modifying the latter in two ways that are relevant for the present argument. First, emplotment ultimately serves the development of fictional character and not vice versa (Ricoeur 2005: 216). Second, Ricoeur generalizes "muthos" to such an extent that it characterizes narrative per se and not only dramatic art (Bläser 2015: 18).

On the one hand, emplotment accounts for coherence inasmuch as the former synthesizes heterogeneity. On the other hand, emplotment also creates pathos and emotionality in the widest sense of catharsis (Ricoeur 1984: 43). Therefore, Ricoeur speaks of two opposing poles at work in emplotment: concordance (synthesis of heterogenous elements) and discordance (unresolved dissonances). The notion of discordance includes reversals (peripeteia) in the story that inflict an unexpected turn on the hero or heroine: The "play of discordance internal to concordance" is the "internal dialectic of poetic composition" (38). Derived from Aristotelian tragedy, Ricoeur's narrative theory, then, can be said to be interwoven with emotionality (especially with pity and fear): "By including the discordant in the concordant, the plot includes the affecting within the intelligible" (44). These reversals trigger readers' emotions for the hero and, in doing so, hamper his comparability insofar as the figure's sustained struggles reinforce readers' imaginings of the very characters as if he were an individual (Ricoeur 2005: 216). In brief, the discordant elements of the emplotment do much to rhetorically suspend the hero's comparability and thus reinforce Oroonoko's literal persona, namely the enslaved African prince. 
That discordance outweighs concordance in the case of Oroonoko underpins my argument about the dynamics of comparability and incomparability. I contend that three reversals in the narrative suspend comparability momentarily, emphasize the hero's action and suffering irrespective of the narratorial commentary, and, in doing so, recalibrate otherwise Eurocentric analogies inherent in the novel. The first part of this article focuses on three major analogies with the Stuart monarchy and Roman history and the second half highlights three major peripeteia - from bliss to sullenness, from enslaver to the enslaved, and from martyrdom to infrahuman spectacle - each of which suggest that the emplotment ultimately transcends Eurocentric analogy. The contradictions in the plot cluster around the materiality of plantation slavery. Instantiating rhetorical incomparability mainly through sullen bliss, the enslaved enslaver, and unwitnessed martyrdom, I propose that Behn makes a virtue out of discordant configuration by constructing her eponymous hero as an exceptional human being (as opposed to a moral exemplar or racialized type). The figure of the entitled West African leader of a slave rebellion galvanizes singularity. In so doing, Behn's tale can be said to establish a hallmark of the novel as a literary genre in terms of formal realism (Watt 1957).

By "rhetorical incomparability", I mean certain textual devices that effectively postpone or suspend comparability. Jean-Jacques Rousseau rightly observed that "[w]hoever sees only a single object has no occasion to make comparison" (qtd. in Cheah 1999: 3). The same applies to whoever only imagines a single person. Having said this, rhetorical incomparability does not rule out the structural ubiquity of comparability (Sass 2020: 94). Rhetorical incomparability in this essay should not be conflated either with "the line of argument - popular within literary studies, where it [...] repeats the discipline's selfdefining reverence for the unique, the particular and the incomparable, while making it seem that the dislike [of comparability] itself is anti-imperialist by its very nature" (Robbins 2013: 191). Anything and anybody can be compared in principle, but one of the innovative virtues of early eighteenth-century novels (and novellas) was the introduction of fictional characters that strikingly resembled real-life people. John Bunyan's allegory The Pilgrim's Progress $(1678,1684)$ features figures that stand in for certain moral types or abstract ideas such as the main character "Christian". By contrast, early novels in English are invested in the imitation of human beings (Bode 2005: 127; Auerbach 1946). Such a fleshing out of fictional character is more likely to occur in text-reader interaction "if no information is presented that would allow easy initial categorization" or comparison (Schneider 2013: 123). For life-like 
characters to emerge from prose fiction, it is vital to postpone comparability to some degree. The rhetoric of incomparability in novels resembles "the suspension of structurally possible comparisons [in other fields such as] in morals and public life as well as in intimate contexts" (Sass 2020: 94). After all, rhetorical incomparability is, Hartmut von Sass notes, a "highly important institution" (ibid.). Eighteenth-century critical readers and philosophers like Rousseau emphasized comparability (Epple/Erhart 2020: 25), but early anglophone novelists nonetheless made a virtue out of postponing comparability by narrative means that evoke the hero's seeming incomparability. In brief, the demands that early novelists made on their readers allowed and even encouraged them to simply follow the life and adventures of their hero. In Behn's case, I propose in Part II of the present essay, such followability does not suspend comparisons for good but reinforces Oroonoko's non-European persona as a West African prince: The peripeteia of the emplotment - sullen bliss, the enslaved enslaver, and unwitnessed martyrdom - are effective in mainly three ways: First, they postpone and arguably even occlude Eurocentric comparisons; second, they evoke Oroonoko as a strong man of action, and, third, they make room for comparisons with the transnational history of slavery. In so doing, they evoke Oroonoko's literal persona, namely as a West African warrior-prince who is unjustly sentenced to be dismembered in the British colony Surinam.

Comparability plays a vital role in the vast scholarship on Behn's foundational novella. "Comparative work", Pheng Cheah notes, "is generally understood as a mode of analysis that begins from one given national or cultural case of subject of legitimate interest, $\mathrm{X}$, which is the basis for forming a provisional hypothesis or working idea about this subject that serves the tertium comparationis" (1999: 3). Methodologically speaking, the grounds of comparison inevitably shape the results and therefore call the "objective basis" of comparisons into question (ibid.). "In the past, the grounds of comparison were undeniably Eurocentric", Cheah claimed in 1999 (3). Part I "The Analogies of Plot" supports Cheah's hypothesis that the bias of comparison in Behn's case is Eurocentric on two levels: that of the primary text, i.e., Behn's novella, as well as that of the critical intervention made by Laura Brown and others.

Drawing on Geoffrey E. R. Loyd, some scholars agree that comparisons can be classified along the axes of five valences: (1) one's own superiority claims, (2) other's superiority, (3) priority of communalities, (4) insurmountable of differences and concomitant incomparability, and (5) novelty (Epple/Erhart 2020: 23). By opposing "the theoretical pitfalls of the 'other"' (1987: 
185), Brown prioritized above all the third valence, namely the communalities between the African hero and the Stuart Monarchs. In this line of argument, scholars have shown how the similarities exoticize the protagonist. My point in Part I is that such an emphasis on communalities with European monarchs unwittingly or wittingly reinforces the Eurocentric bias of comparisons; indeed, the emphasis on communalities with the Stuarts has effectively occluded the novella's potential for lateral comparison, for instance, the work's comparability with the transnational history of slavery (even if Brown tried to salvage the latter). By "lateral comparison", I mean the modes of comparability that "balance the 'frontal comparisons' of 'us' and 'them' as practiced in much traditional as well as in postcolonial anthropology" (Epple/Erhart 2020: 17). As an alternative to Brown's communality-focused comparisons, Part II of this essays suggests that the novelty of Oroonoko's story at the time warrants a lateral comparison with the transnational history of slavery.

\section{The Analogies of Plot}

The narrative configuration of Oroonoko partly does run parallel to the historiography of the Stuart Monarchs, with Charles I and also with Charles II and James II. In its beginning, middle and end, the short novel establishes suggestive analogies between the murdered West African crown prince and English historiography from the Civil Wars to the Glorious Revolution. Charles I features initially in the narrator's reference to Oroonoko's aristocratic breeding and education. Much narratorial emphasis is placed on Oroonoko's knowledge of "the late Civil Wars in England, and the deplorable Death of our great Monarch" and Oroonoko's moral judgement that this execution means an "Abhorrence of the Injustice" (Oroonoko, 1995: 62). The hero's knowledge of British politics and his evaluation thereof operate as narratorial recommendations. They work as attempts to assimilate Oroonoko's manner and moral compass into some equivalent of "some European Court" (ibid.). These statements thus seemingly align Oroonoko with Restoration ideology: first, the royalist position in mid-seventeenth-century English politics; secondly, the indefeasibility of the monarchy; and, thirdly, the glorification of Charles I.

Parts of the middle section in the narrative reinforce this parallel. Upon arrival in British colonial Surinam, which completes a series of events consisting of the kidnapping, the Middle Passage, the enslavement and commodification of the African prince, readers learn that the overseer of the Lord 
Governor's plantation gives Oroonoko a new name as a rite of passage into enslavement: "Mr Trefry gave Oroonoko that of Caesar, which Name will live in that Country [Surinam] as long as that (scarce more) glorious one of the great Roman" (Oroonoko, 1995: 88). It is commonly accepted that "Caesar" is the code name Behn used for the Stuart kings in her other writing (Doyle 2008: 103). Long after the death of Charles I in 1649, Behn and her audience had lived under the rule of Charles II until he passed away in 1685 and James II succeeded to the throne. Charles II is Caesar in Behn's "poem 'A Farewell to Celladon on His Going Into Ireland' (1684) as is James II in her poem 'Poem to Her Sacred Majesty Queen Mary' (1689)" (Brown 1987: 199). Analogous to that, Oroonoko alias Caesar can be said to personify three English monarchs at once while the analogies match above all the two failed kings in need for mystification, Charles I and James II.

Progeny features as a thematic catalyst for the intradiegetic crisis in a way that compares to the Glorious Revolution. It is Imoinda's pregnancy that precipitates Oroonoko's rebellion since revolt offers the only option for escape from the enslavement of their offspring (Sussman 1993). Central as reproduction is to dynasties, this emplotment has been said to run parallel to the birth of James II's son in 1688 and the Catholic king's deposition (Guffey 1975; Miller 1982: 541). This analogy fails to consider the unpopularity and arbitrariness of this British ruler, who according to Whig and Tory parliamentarians had "tried to destroy the constitution and impose popery and absolutism" (Miller 1982: 545). Nonetheless, it is fair to say that the birth of James' heir spurred on the rebellion (against James II) since the male progeny entailed the threat that the next ruler of England "would be, not one of James' Protestant daughters, Mary or Anne, but a Catholic son" (Page/Sonnenburg 2003: 236). In addition, Surinam belongs to the British history of Dutch usurpation. The intradiegetic location thus aligns the English colonial defeat in 1667 with William of Orange's, "the Dutchman's", seizing the English throne in 1688.

If we read Oroonoko as such an allegory for the Glorious Revolution, the signification of the eponymous hero is reduced to universalist claims of royal bloodlines and the meaning of his enslavement by white colonisers dwindles into a hazy figure for the threat of illegitimate rule, social unrest in the wake of the deposition of the legitimate monarch, and the jeopardy of the "patrilineal ideology" of landownership (Pacheco 1994: 500). This reductive analogy can be extended to the indefeasibility of the English monarchy even at the expense of Anglican Protestantism, which opens up questions concerning the 
author's biography and her loyalism to the Stuart kings that lie outside of the theoretical frame of the present analysis of narrative configurations.

The beheading of Charles I has served as a tertium comparationis for the brutal, graphic ending of Oroonoko. "For Behn and others", Brown notes, "the colonies stage an historical anachronism, the repetition of the English revolution, and the political endpoint of Behn's narrative is the re-enactment of the most traumatic event of the revolution, the execution of Charles I" (Brown 1987: 197). In the novella's final section, Behn's principal character is confined to Parham Hill and thus protected from his persecutors so that he can recuperate as far as possible from the horrific torture the British inflicted on him after the revolt. However, as the personification of evil tyranny, the Deputy Governor Byam calls in his council consisting of "notorious villains" from Newgate prison (Oroonoko, 1995: 112), sentences Oroonoko to death, kidnaps him once again and has him quartered at the hands of the Irish henchman Banister. As Oroonoko is being brutalized to death, he remains stoic "without a Groan, or a Reproach" (118).

These events correspond roughly with the execution of the English king in 1649. Charles I was imprisoned, tried for treason, and beheaded by a small group of Members of Parliament called the "Rump" following his defeat in the Civil Wars. Behn's configurations echo, according to Doyle, the "language used in sympathetic Restoration histories and biographies of Charles, revealing the close connection" (2008: 103). These texts represent Charles I as the heroic martyr, who betrays no sign of fear at the verge of imminent death (Brown 1993: 58). Moreover, the figure of the "wild" Banister resembles the descriptions of the "absolute barbarity" of the king's executioner (Doyle 2008: 103). Inasmuch as these royal hagiographies recount the dismemberment of the king's corpse and the parading of his body parts in London streets, Behn's narrator recalls how the pieces of Oroonoko's remains, the "frightful spectacle of a mangle'd king" (Oroonoko, 1995: 118), are sent across South American plantations. Along these lines, the fictional life narrative of Oroonoko appears basically as a surrogate for the commemoration of English kings and English glory in the 1640s, 1660s, and 1680s. In these terms alone, the narrative configuration of Oroonoko would amount to an exoticized version of the English trauma of regicide.

But "there is no simple political allegory in Behn's novella" (Brown 1987: 197). Critics tend to overlook that, irrespective of Behn's codename, Julius Caesar was also "the perhaps most celebrated victim" of kidnapping from a coastal region (Patterson 1982: 115). Ransom was paid and Caesar freed. But 
Caesar stepped in, according to Plutarch, to crucify his captors himself once they had been caught (Osgood 2010). Oroonoko's fate matches Plutarch's historiography insofar as the narrative configuration begins with the analeptic representation of Oroonoko's royal ancestry and military achievements in the storyworld called Coromantien, continues on the slave ship and then in Surinam with Oroonoko's failed attempts to negotiate his release and that of others against a ransom - "either Gold, or a vast quantity of Slaves" (Oroonoko, 1995: 93) - and ends with his thwarted plan to take revenge on the villain Byam and "all those he thought had inrag'd him [sic!]" (113). ${ }^{2}$ Crucially, the analogy with Julius Caesar's kidnapping does not extend to the Roman's liberation and revenge on the captors. It is Oroonoko who is quartered in the end. Nonetheless, Plutarch's subtext opens up an analogy that casts not only the villains, Byam and Banister, but also the supposed colonial benefactors, the plantation overseer Trefry and Colonel Harry Martin, into the mould of a band of mean pirates.

The significance of the narrative incorporation of Plutarch's histography leads beyond the analogy with late seventeenth-century domestic politics since it provides a subtext for the re-enactment of British imperial history of enslavement and slave revolt in the West Indies and Guiana. That Roman history and in particular the English version of Plutarch's Lives of the Noble Grecians and Romanes (1579) offers parallels for the intradiegetic slave rebellion is a rhetorical move that features prominently in Oroonoko's important anti-slavery speech. Oroonoko appropriates the legend of Hannibal for his revolt (see also Oroonoko, 1995: 93). The assimilation of Hannibal is part of the rhetorical feat that helps Oroonoko to regain the support of his former slaves and fellow Africans (453, fn. 93). For Oroonoko compares himself to Hannibal and the flight from the plantation to Hannibal's crossing of the Alps: "He told them that he had heard of one Hannibal a great Captain, had Cut his Way through the Mountains of solid Rocks; and shou'd a few Shrubs oppose them; which they cou'd Fire before 'em [sic!]?" (106). The significance of this comparison is disputed. Commentators have explained Oroonoko's summoning of Hannibal in terms of racial identity: "This is a black pride incarnate" (Polk 2000: 158; see also Margaret Ferguson 1994: 170). Derek Hughes notes that "Hannibal, however, was not black, or even African. The Carthaginians were 
Phoenician colonists in North Africa" (2002: 9). ${ }^{3}$ What remains undisputed, however, is Hannibal's reputation as one of the great military leaders of antiquity and as the most dangerous obstacle to Roman global dominance during his lifetime. The comparison thus flatters both parties: the African rebels and the British slaveholders.

The comparison with Hannibal highlights a virtue of the African prince that tends to be overlooked, namely Oroonoko's military prowess. Critical assessments largely focus on Oroonoko's whitewashed physiognomy, Eurocentric education, and commodification as a pet slave (Aravamudan 1999: 29-70; Brown 1987: 187). But the length of narratorial commentary dedicated to European assimilation should not distract scholarly attention from Oroonoko's military achievements in Coromantien at a very young age. After all the African backstory begins with Oroonoko's military promotion to the rank of general in the army and his victorious intervention in a two-year war at the tender age of seventeen. This is to say that in contrast to court-centred medieval romances like Roman de la Rose, Behn's novella begins with the hero's absence from court. Overall, the young prince spends more than ten years in the company of "fighting Men, or those mangl'd, or dead; who heard no Sounds, but those of War and Groans" (Oroonoko, 1995: 62). What underpins the narrative discourse on Oroonoko's looks and gallantry is the emplotment of his leadership legitimized not only by royal birth but also earned by military merit and his other pursuits of honour. Having said this, the comparison with Hannibal does not only help to throw Oroonoko's bellicose acumen into relief, but the analogy also keeps counterhegemonic formations in check: the comparison signals that the enslaved African general will be the defeated by the British colonisers, inasmuch as Hannibal ultimately loses his battles against Rome.

\section{The Peripeteia of Plot}

New Historicism has taught us that a work of literature does not exist in a vacuum (Greenblatt 1995). Through this lens claims of incomparability per se become indefensible. However, New Historicism has a blind spot insofar

3 Derek Hughes reviews key texts from Sepúlveda and Las Casas through Arthur, Comte de Cobineau on the discursive formation of "race" in the late seventeenth century (2012). 
as fictional narratives like Behn's powerful novella also convey a pathos that interrupts and recalibrates underlying comparability. In this regard, the remainder of this essays departs from the New Historicist analysis in the wake of Braun's influential essay. I provide instead an alternative interpretation of Behn's novella by combining the premise of what Sass has called "the dimension of an ethics of comparison" and the ethics of reading based on Ricoeur (Sass 2020: 95; Ricoeur 1988).

Rhetorical or "performative incomparability implies [as mentioned] structural comparability" (Sass 2020: 95). Incomparability in a work of literature is rhetorical insofar as it suggests a refusal to compare while the structural comparability of the work persists. If incomparability is a matter of rhetoric, as Sass claims, it is also a matter of affect. Brown largely failed to take the role of affects into consideration. Paying close attention to the ways in which emplotment stirs affects, I argue that Behn's emplotment (I) engages readers so thoroughly in the hero's action and suffering through the horrific trials he encounters that it reinforces the African hero's literal persona and, in doing so, undermines Eurocentric comparisons and (2) redirects them towards lateral comparisons such as with the transnational history of slavery.

Central to the present interpretation is my contention that incomparability in the case of Behn's novel is rhetorical and evokes primarily an affective disposition. "Nothing compares to you" is not only the title of Prince's pop song covered by Sinéad O'Connor (Sass 2020: 91), the Oxford English Dictionary also tells us that one of earliest recorded meanings of "incomparable" is meant in the affective sense of "matchless", "peerless", and "transcendent" such as the record dated to 1662 in Thomas Elyot's The Castle of Helthe: "She was afterwards his incomparable wife" (OED 2021). Behn composed the plot in such a way that readers follow Oroonoko's trials and tribulations in the narrated world and not Charles I's tribunal and execution. The emplotment conveys rhetorical incomparability insofar as the novelistic evocation of pity and fear depends on Oroonoko's actions. The peripeteia direct readers' attention away from Eurocentric comparisons inasmuch as these moments of sudden reversal in the hero's fortunes compare above all to specific elements of West African culture as well as plantation slavery.

By tracing Oroonoko's action and suffering in the second part, my essay contributes to a specific debate in Anglo-American literary criticism. Current scholarship about the role of affect and Ricoeurian hermeneutics is embroiled in the debate about "postcritical reading" spearheaded by Rita Felski's Uses of Literature and other publications (e.g. Anker/Felski 2017; Felski 2020). "Post- 
critical reading" is defined by a goal rather than a methodology, namely "to do better justice to the transtemporal liveliness of texts and the coconstitution of texts and readers - without opposing thought to emotion or divorcing intellectual rigor from affective attachment" (Felski 2015: 154). The proponents of postcritique broadly follow Eve Kosofsky Sedgwick's shift from paranoid to reparative reading, intending to recast literary criticism as an affective and critical practice (Sedgwick 2002). My line of argument is sympathetic to this aspect of "postcritical reading" but not the entire polemic (see Landy 2020). I agree "that critique is as much a matter of affect and rhetoric as of philosophy or politics" (Felski 2015: 3). In this spirit, my interpretation of Oroonoko suggests that the lateral comparisons in Behn's novel are reinforced and even driven by Oroonoko's rhetorical incomparability insofar as it focuses attention on his character development. At the same time, however, my uses and understanding of "neophenomenology" (Felski 2015: 191) are diametrically opposed to Felski's reduction of Ricoeur's hermeneutics. Felski caricatures Ricoeur as a hardened hermeneut in whose view "[m]eaning can be retrieved only after arduous effort; it must be wrested from the text, rather than gleaned from the text" (Felski 2015: 31). From the vantage point of postcritical reading, the hermeneutics of suspicion serves merely as a foil in the recalibration of literary criticism. Collapsing Ricoeur's entire theory of narrative into the hermeneutics of suspicion, postcritical reading has so far failed to consider Ricoeur's Time and Narrative and other writings that actually elucidate affective styles and modes of reception. In this respect, I emphatically depart from postcritical reading and draw on Ricoeur's narrative and reception theory, conceptualising the rhetorical incomparability in Behn's novel in the aforementioned terms of emplotment as the interplay of concordance and discordance (Ricoeur 1984, 1985, 1988).

Emplotment suits the analysis of Behn's contradictory novella because the Ricoeurian concept provides insights into the internal dynamic of the narrated actions independent from narratorial commentary. The homodiegetic white female narrator in Oroonoko colours the events in the shades of western standards of evaluation (see Nadine Boehm-Schnitker's article in this volume). The present essay focuses instead on Oroonoko's actions as presented in the narrative composition in order to eschew the opinionated narrator. It is Oroonoko's actions that provide readers with a perspective that leads beyond the comparisons with British and Roman historiography; indeed, it is Oroonoko's actions and suffering that transcend an allegory of the Glorious Revolution. This excess of meaning erupts above all at the points of config- 
uration of plantation slavery. These unsettling formations take primarily the shape of three important reversals: sullen bliss, the enslaved enslaver, and unwitnessed martyrdom.

It is at midpoint in the novella that the testimonial configurations clash head-on with Eurocentric history and romance. Consequently, incomparability begins to outweigh comparability within the overall narrative configuration. Crucially, the supposed happy ending of the conventional marriage plot - Oroonoko and Imoinda's wedding - entails a perfidious reversal: the incompatibility of slavery and marriage turns bliss into "sullenness" (Oroonoko, 1995: 93). This incompatibility has to do with the material conditions of slavery.

According to Orlando Patterson, enslaved persons are alienated from their social order. This alienation is the reaction to and result of their coercion into total submission to the master. Patterson's "celebrated" comparative study of slavery is designed to identify the "inner dynamics" and "institutional patterns" of slavery (Patterson 1982: ix; Gilroy 1993: 63). The sociologist influentially theorized slavery as the state of social death: "the man who was enslaved was in a permanent condition of liminality and must forever mourn his own social death" (Patterson 1982: 60). Slaves are socially dead to the extent that they are "alienated from all 'rights' or claims of birth" and thus cease to belong in their own right to "any legitimate social order" (5). Enslavement involves the loss of social existence other than under the master's dominance and thus "the incorporation of the slave into the marginal existence of the permanent alien" (54). That this alienation extends to marriage rights is dramatized in Oroonoko.

When Oroonoko and Imoinda marry and conceive a child, marriage fails one of its main purposes: the legitimisation of progeny and of the custodial powers of parents. The hereditary status of slavery precludes marriage from fulfilling these very functions (Patterson 1982: 187). One of the crucial differences between Oroonoko's parentage situation and that of the English king James II lies in the fact that plantation slavery contributed substantially to the erasure of family trees among the descendants from enslaved Africans in the West Indies: "One of the most important findings of Michael Craton's study of the oral history of the descendants of the Worthy plantation slaves of Jamaica" (6) was the near impossibility "to trace precise lineage" (Craton 1978: 374-375). In the storyworld, the dissolution of the parental rights, which marriage otherwise secures, contributes to the social death of slavery, too: "This Thought made him [Oroonoko] very uneasy and his Sullenness gave them [the enslavers] some Jealousies of him" (Oroonoko, 1995: 93). The pregnancy brings the alienation inherent in slavery into focus and renders Oroonoko and 
Imoinda's happiness sullen. Behn configures the masculine drive to preserve patrilineal ancestry as a major cause for Oroonoko's decision to challenge his British enslavers after all: "This new Accident [Imoinda's pregnancy] made him more Impatient of Liberty" (ibid.). The collision of the romance configurations of the Anglo-Roman comparison with the testimonial configurations of hereditary plantation slavery thus marks a major turning point within the emplotment of Oroonoko. This discordance tends to move readers and inspire compassion.

Another reversal that distinguishes Behn's novella consists in the enslavement of the enslaver. Commentators have regarded the fact that Oroonoko "is described as having captured and sold black slaves in African wars before he himself was enslaved" as an ideological indicator for the whole work of fiction. Margaret Ferguson, for instance, interprets such "civilised' doubleness" as an endorsement of "the privileges of the nobility with the profits of the slave trade" (Margaret Ferguson 1994: 179). This argument disregards the heterogeneity of slavery, overlooks the exceptional brutality of plantation slavery in the West Indies and reinforces the Western polarisation of "slaves and nonslaves" (Patterson 1982: 27; Patterson 1967; Mintz 1986: 48-51).

Historians of slavery conceive of a spectrum between two extremes of slavery. In his foundational monograph Many Thousands Gone, Ira Berlin distinguishes between a "society with slaves", where slavery exists but does not function as the dominant labour system, and a "slave society", where slavery represents the dominant form of labour and shapes every other social relationship within that society (between man and women, parents and children, husbands and wives, workers and bosses, as well as rulers and rules). Far from justifying slavery, the distinction offers a way to differentiate between West Indian plantation slavery and certain forms of African slavery rather than conflating them as the same evil. The abolitionist pamphlet, written by the former slave trader John Newton and published in 1788, compared British with African slavery as follows:

The state of Slavery, among these wild barbarous people, as we esteem them, is much milder than in our colonies. For as, on the one hand, they have no land in high cultivation, like our West-Indian plantations, and therefore no call for that excessive, unintermitted labour, which exhausts 
our Slaves; so on the other hand, no man is permitted to draw blood, even from a Slave. (1788: 15-16) ${ }^{4}$

According to Newton, enslaved labour at the sugar plantations in the Caribbean was merciless whereas slavery among Africans was "much milder". Newton's pamphlet appeared in 1788, but the use of African labour at sugar factories and plantations was already in place since the middle of the seventeenth century. Sidney W. Mintz has established the argument in economic history that the preindustrial state of seventeenth-century British society does not preclude the "recognition of the industrial aspects of plantation development" in the West Indies during the period (1986: 49). Slaves in the sugar factories, for instance, worked "continuously in shifts lasting all day and part of the night, or the whole of every second or third night" (50). The homodiegetic narrator describes this economy: "Those then whom we make use of to work in our Plantations of Sugar, are Negro's [sic!], Black-Slaves altogether" (Oroonoko, 1995: 60). The configurations of Oroonoko as the enslaved enslaver, which the eponymous "royal slave" anticipates, captures the heterogeneity of slavery mentioned by Newton and studied in the history of slavery. The figure of enslaved African enslaver points to aspects of the African practice of slavery in terms other than those of the Western ideology of freedom.

Oroonoko features initially as an enslaver of Africans when he presents the prisoners he has taken in battle to the daughter of the general who gave his life in order to save the prince: "Oroonoko coming from the Wars [...] thought in Honour he ought to make a Visit to Imoinda, the Daughter of his Foster-father, the dead General [...] to present her with those Slaves that had been taken in this last Battel, as the Trophies of her Father's Victories" (Oroonoko, 1995: 6364). The scene configures the enslavement of the defeated soldiers as an act of honour attributed to both the killed general and to the victorious prince. The figuration suggests that Oroonoko's reputation as an African hegemonic male depends on the number of dependents he can obtain. It matches the sociological data for sub-Saharan Africa gathered by Patterson, who shows that power and honour are intricately linked in enslavement practices (1982: 79, 11). According to Patterson, slavery served as a means alongside kinship and

For a discussion of the contemporary relevance of the conflation of different types of slavery see Akala's Natives: Race and Class in the Ruins of Empire (2019: 139). For more information about John Newton see the entry in Postma's The Atlantic Slave Trade (2003: 95-96). 
affinal relations for an "ambitious man" to acquire prestige, which is "critical in all African societies" (1982: 83; see Athey and Alarcón 1993: 443, fn. 41). The dishonour experienced by the enslaved prisoners of war directly serves the prince's honour, bolstering his social status and appeal for his love interest Imoinda. Her appreciation reinforces the hero's honour rhetorically.

Furthermore, the figure of the enslaved enslaver contains configurations of African cultures, probably those of the Ashanti people. Scholars have observed that Oroonoko's invented homeland is named after a West African trading post formerly used by English and Dutch slave merchants (Hughes 2012: 127). According to Susan Andrade, "Coromantien, also spelled Coromantyn and Koromanty, was the name given in the New World to ethnic groups like the Ashanti, who came from the interior of the African Gold Coast, now Ghana" (1994: 209). Moira Ferguson notes that "people from that region in question would have spoken Ashanti, Fanti, and possibly some less widely spoken languages such as Twi or Ga" (1992: 342). The configuration of Oroonoko's social relations in Coromantien and in particular his enslavement of prisoners of war runs parallel to customs in a society with slaves like the early Ashanti kingdom in West Africa, also known as Asante. ${ }^{5}$

The author-narrator describes Oroonoko above all as "Prince" and "General" (Oroonoko, 1995: 63). The configuration of Oroonoko, his military merit, his gold and slave resources bear witness to a struggle for hegemonic masculinity in African societies of the period if one follows the character development closely. That Oroonoko belongs to the highest ranks of his society is literally inscribed in his face: the sides of his temples feature the cutaneous carvings of animals, such as "a little Bird" (92). Yet birth alone does not secure his social status. Oroonoko's constant efforts to reinforce his prestige are apparent from his long-standing preoccupation with war and slave trade in the Coromantien narrative, which resonates with the figure of the "big men" and chiefdoms in African history. His struggle for prestige continues even in the conflicted terms of slavery in the Surinamese part of the story. While in the British colony, it is Oroonoko who re-establishes, for instance, after a period of violent confrontation, peaceful relations between the indigenous inhabitants that allow him and the English "open, and free Trade with 'em" (103). This configuration resonates with West African culture. The Asante emerged

"Asante." Encyclopedia Britannica, 26 January 2021. 〈https://www.britannica.com/topic/As antes. See also Ivor Wilks who traces the history of the Asante, one of the most powerful peoples of Chana, from the fifteenth century onwards (Wilks 1993). 
from the Akan states at the close of seventeenth century (Wilks 1993). The ethnic group is reported to have the "popular proverb [...] If you have not a master, a beast will catch you" (Patterson 1982: 27). The early Asante were a tribal community in which boundaries of social order were porous enough to allow for, and even to fuel, the competition for prestige (Wilks 1993: 95-98; Patterson 1982: 83). This competition extended to any so-called "abirempon (big men)", who endeavoured to establish themselves as dominant hegemonic males by engaging in the Atlantic slave trade and using slave labour to clear land and found villages (Miescher 2019:40). The intradiegetic designations "Prince" and "General" for Oroonoko echo the "abirempon".

According to Patterson, the power structures among the colonial Ashanti are typically "personalistic", which means that power structures are direct and open and that the principle of kinship played a crucial role in them (Patterson 1982: 19). Patterson describes the personalistic power idiom as a network of interdependences, which exists irrespective of any Western notions of freedom: "the most unslavelike person was the one in whom a small number of claims, powers, and privileges were spread over a large number of persons; the slave, on the other hand, was someone in whom a large number of claims, privileges and powers were concentrated in a single person [the master]" (27). Within this framework, the only way for a slave to achieve privileges and powers was through the master.

This interdependence goes some way to account for the reversal of fortune that turns the enslaver into the enslaved and for the relation between Oroonoko and his former slaves in Surinam as well. The first response of the enslaved Africans at Parham Hill plantation when they recognize their former slaveholder in Oroonoko is grief. When Oroonoko assures them "he was no better" than "their Fellow-Slave", they deem this piece of news worthwhile "Mourning and condoling" (Oroonoko, 1995: 89). The enslavement of their master entails the dissolution of the little access to privileges and power they once had (through him). In traditional African societies, Patterson notes, the difference between enslaver and slave was "difficult for an outsider" to ascertain and came down to the "honorlessness of the slaves" (1982: 83). Oroonoko resists such honourlessness; that is, he insists on his honour despite his enslavement. Holding on to his former status as master, he is able to immediately command respect from his former and other fellow slaves when he decides to rebel. Oroonoko's act of rebellion entails the resumption of his former role as master by representing himself as their access to high social status, a state that the narrator calls "free", once they all escape and return to "his kingdom" 
(106). Accordingly, Oroonoko then takes charge of the collective flight from the plantation, which constitutes the act of rebellion. Oroonoko's powerful speech reinforces his status as the hero of narrative and invites readers to side with the black rebels.

The representation of the majority of slaves (except for Oroonoko, Tuscan and Imoinda) has been understood as a justification of plantation slavery, dehumanisation and racialisation of Africans. Richard Frohock notes that "Behn's narrative implies that the vast majority of enslaved Coramantiens are naturally suited to their position in the colonial economy" (Frohock 1996: 442). The figure of the African enslaved enslaver complicates this view. Put simply, the narrative configuration shows the power of plantation slavery to trump and dismantle the power of all existing social relations between husband and wife, parents and children, but also (milder) forms of slavery of African societies with slaves.

Crucial to the configuration of the anonymous crowd of Africans on the plantation is their final acceptance of the British masters as their only option to remain alive irrespective of any other former claims, privileges, or power they once had. This resignation manifests itself in the African slaves' participation in Oroonoko's beating. Inasmuch as Oroonoko is defeated in his rebellious struggle for mastery, his former slaves lose his protection (as a master) again and, in turn, become complicit in his public humiliation. The configuration of the failed revolt - the defeat, Bynam's betrayal of the written contract of surrender, and Oroonoko's extremely brutal public flogging - operates as the materialisation of Western plantation slavery in the story. Oroonoko's furious condemnation of the slaves' cowardice - "he was asham'd of endeavoring to make those Free, who were by Nature Slaves" (Oroonoko, 1995: 109) - sets an end to his aspirations to act as the conduit to privileges for his former slaves and expresses his particular outrage about the cowardice of his countrymen. Moreover, the configuration of the Deputy Governor's betrayal the disregard of the written terms of surrender - and the total humiliation of the whipping marks the turn from Oroonoko's wish to regain his full honour towards the ardent desire for revenge on Bynam and his accomplices.

The third and final reversal features in the execution scene at the end of the novella: unwitnessed martyrdom. The analogy of Oroonoko's quartering with the decapitation of Charles I disregards a crucial difference in Behn's configuration. The scene of Oroonoko's slaughter takes place in the absence of the prime witness, the homodiegetic narrator. This absence is crucial for the distinction between the representations of martyrdom and testimony ac- 
cording to Aleida Assmann. 'Martyrdom' is derived from Greek 'martys' and "refers to the witness in the religious sense" (Assmann 2006: 268). The lexemes "martyr and martyrdom maintain an important link with the highly symbolic act of witnessing, as developed in the three monotheistic religions and immediately related to persecution and violent death" (ibid.). Martyrs in Judaism, Christianity and Islam undergo violent death and, in doing so, triumph over their persecutors. For the violent public death to attain the symbolic meaning of martyrdom, the martyr "depends on someone to witness the suffering, to identify him or her as a martyr (rather than a justly persecuted rebel), and to codify the story for future generations" (ibid.). Such witness and codification exist for Charles I (to attain the symbolic meaning of martyrdom), but the author-narrator's absence from the scene of execution bars the figuration of Oroonoko from it.

However, the narratorial absence corroborates the configuration of the final scene as a testimony in the tradition of ancient Greek tragedy and Shakespearean drama, according to which the messenger conveys the news of the catastrophe from which he has escaped. To quote the dying Hamlet, in act 5, scene 2, when he asks Horatio to be his witness: "Absent thee ... in this harsh world draw thy breath in pain, to tell my story" (qtd. in Assmann 2006: 267268). The function of the witness is to describe "what cannot be brought onto the stage, in the name of those who are no longer able to speak for themselves" (Assmann 2006: 268). Likewise, the author-narrator is removed from the scene of horror while the last sentence of her testimonial configuration omits the main subject's name: "to make his Glorious Name to survive to all ages; with that of the Brave, the Beautiful and the Constant Imoinda" (Oroonoko, 1995: 119).

The testimonial register of the final scene is consistent with the notion of slavery as social death. Inasmuch as slavery brings about the "secular excommunication" of the enslaved (Patterson 1982: 5), the latter and in particular the enslaved African man is excluded from the powerful symbolism of martyrdom in Western representation. There is no possibility for triumph in the configuration of Oroonoko's death. Faith is not at stake in this scene, nor collective identity, nor solidarity or compassion (see Griffin 2019). Instead, the scene graphically configures torture with the exception of the pipe as a token of remaining masculine dignity. The scene, first published in London in 1688, influentially configures the iconography of the brutalized male black body, which has been remediated and fetishized in multiple media up to the present day (as such in the case of the video recordings of the murder of George Floyd 
by a U.S. policeman on $25^{\text {th }}$ May 2020). At the same time, the narrative by virtue of its written composition and thanks to the literary acumen of its author represents readers up to the current day with the troubling discordances that challenge Western understandings of the relation of master and slave.

Having said this, the ending does not determine the significance of the entire narrative. The contradictions in Oroonoko's actions embedded in the storyworld resist the complete infrahuman codification of the final paragraphs (Gilroy 2000: 22). Crucially, the peripeteia of the plot lend Behn's hero the singularity that distinguishes this figure in literary history, transcends the operations of the then nascent racialized typologies as well as those of the moral exemplar and elevates him to the level of an exceptional human being: "this Great Man" (Oroonoko, 1995: 56). The incomparability inherent in the actions of the enslaved African warrior-prince thus corroborates the foundational role of Aphra Behn's Oroonoko in the emergence of the novel as a literary genre.

\section{Bibliography}

Akala. Natives: Race and Class in the Ruins of Empire. London: Tworoadsbooks, 2019.

Alkon, Paul. "Recent Studies in the Restoration and Eighteenth Century." Studies in English Literature, 1500-1900 29.3 (1989): 579-620.

Andrade, Susan Z. "White Skin, Black Masks: Colonialism and the Sexual Politics of Oroonoko." Cultural Critique 27 (1994): 189-214.

Anker, Elizabeth S. and Rita Felski, eds. Critique and Postcritique. Durham: Duke University Press, 2017.

Aravamudan, Srinivas. Tropicopolitans: Colonialism and Agency, 1688-1804. Durham: Duke University Press, 1999.

Aravamudan, Srinivas. "What Kind of Story Is This?" Approaches to Teaching Behn's Oroonoko. Ed. Cynthia Richards and Mary Ann O'Donnell. New York: MLA, 2014. 27-33.

Assmann, Aleida. "History, Memory, and the Genre of Testimony." Poetics Today 27.2 (2006): 261-273.

Athey, Stephanie and Daniel Cooper Alarcón. "Oroonoko's Gendered Economies of Honor/Horror: Reframing Colonial Discourse Studies in the Americas." American Literature 65.3 (1993): 415-443.

Auerbach, Erich. Mimesis: Dargestellte Wirklichkeit in der abendländischen Literatur. Bern: Francke, 1946. 
Azim, Firdous. The Colonial Rise of the Novel. London: Routledge, 1993.

Behn, Aphra. The Works of Aphra Behn. The Fair Jilt and Other Short Stories. Ed. Todd, Janet. Vol. 3. 7 Vols. Columbus: Ohio State University, 1995.

Berlin, Ira. Many Thousands Gone: The First Two Centuries of Slavery in North America. Cambridge: Belknap Press of Harvard University Press, 1998.

Bläser, Stefanie. Erzählte Zeit-Erzähltes Selbst: Zu Paul Ricoeurs Begriff der narrativen Identität. Berlin: Pro Universitate Verlag, 2015.

Bode, Christoph. Der Roman. Tübingen: UTB Verlag, 2005.

Botelho, Keith M. "Credibility and Truth in Oroonoko." Approaches to Teaching Behn's Oroonoko. Ed. Cynthia Richards and Mary Ann O’Donnell. New York: MLA, 2014. 34-38.

Britland, Karen. “Aphra Behn's First Marriage?" The Seventeenth Century (2019): 1-21.

Brown, Laura. Ends of Empire: Women and Ideology in Early Eighteenth-Century English Literature. Ithaca: Cornell University Press, 1993.

Brown, Laura. "Romancing the Empire: Oroonoko and the Trade in Slaves." The New Eighteenth Century: Theory, Politics, English Language. Ed. Martha C. Nussbaum and Laura Brown. New York: Methuen, 1987. 41-61.

Cheah, Pheng. "Grounds of Comparison." Diacriticis 29.4 (1999): 1-18.

Chibka, Robert L. “Oh! Do Not Fear a Woman's Invention': Truth, Falsehood, and Fiction in Aphra Behn's Oroonoko." Texas Studies in Literature and Language 30.4 (1988): 510-37.

Craton, Michael. Searching for the Invisible Man: Slaves and Plantation Life in Jamaica. Cambridge: Harvard University Press, 1978.

Doyle, Laura. Freedom's Empire: Race and the Rise of the Novel in Atlantic Modernity, 1640-1940. Durham: Duke University Press, 2008.

Epple, Angelika and Walter Erhart. "Practices of Comparing: A New Research Agenda between Typological and Historical Approaches." Practices of Comparing: Towards a New Understanding of a Fundamental Human Practice. Ed. Angelika Epple, Walter Erhart, and Johannes Grave. Bielefeld: Bielefeld University Press, 2020. 11-38.

Felski, Rita. "Good Vibrations." American Literary History 32.2 (2020): 405-415.

Felski, Rita. The Limits of Critique. Chicago: University of Chicago Press, 2015.

Felski, Rita. Uses of Literature. Oxford: Blackwell, 2008.

Ferguson, Margaret. "Juggling the Categories of Race, Class and Gender: Aphra Behn's Oroonoko." Women's Studies 19.2 (1991): 159-181.

Ferguson, Margaret. "News from the New World: Miscegenous Romance in Aphra Behn's Oroonoko and The Widow Ranter." The Production of English Re- 
naissance Culture. Ed. David Lee Miller, Sharon O'Dair, and Harold Weber. Ithaca: Cornell University Press, 1994. 151-189.

Ferguson, Moira. "Oroonoko: Birth of a Paradigm." New Literary History 23.2 (1992): 339-359.

Frohock, Richard. "Violence and Awe: The Foundations of Government in Aphra Behn's New World Settings.” Eighteenth-Century Fiction 8.4 (1996): 437-452.

Gadamer, Hans-Georg. Truth and Method. Wahrheit und Methode. Trans. Joel Weinsheimer and Donald G. Marshall. 2nd ed. London: Continuum, 1989. Gilroy, Paul. Against Race: Imagining Political Culture Beyond the Color Line. Cambridge: Belknap Press of Harvard University Press, 2000.

Gilroy, Paul. The Black Atlantic: Modernity and Double Consciousness. London: Verso, 1993.

Goreau, Angeline. Reconstructing Aphra: A Social Biography of Aphra Behn. New York: Dial Press, 1980.

Greenblatt, Stephen. "Culture." Critical Terms for Literary Study. Ed. Frank Lentricchia and Thomas Mclaughlin. 2nd ed. Chicago: Chicago University Press, 1995. 225-232.

Griffin, Megan. "Dismembering the Sovereign in Aphra Behn's Oroonoko." ELH 86.1 (2019): 107-133.

Guffey, George. "Aphra Behn's Oroonoko: Occasion and Accomplishment." Two English Novelists. Ed. George Guffey and Andrew Wright. Berkeley: University of California Press, 1975. 2-41.

Hughes, Derek. "Blackness in Gobineau and Behn: Oroonoko and Racial Pseudo-Science.” Women's Writing 19.2 (2012): 204-221.

Hughes, Derek. "Race, Gender, and Scholarly Practice: Aphra Behn's Oroonoko." Essays in Criticism 52.1 (2002): 1-22.

Hughes, Derek. Versions of Blackness: Key Texts on Slavery from the Seventeenth Century. Cambridge: Cambridge University Press, 2007.

Landy, Joshua. "In Praise of Depth: Or, How I Stopped Worrying and Learned to Love the Hidden." New Literary History 1.51 (2020). 145-176.

Lipking, Joanna. "'Others,' Slaves, and Colonists in Oroonoko." The Cambridge Companion to Aphra Behn. Ed. Derek Hughes and Janet Todd. Cambridge: Cambridge University Press, 2004. 166-187.

Miescher, Stephan F. "Masculinities." A Companion to African History. Ed. William H. Worger, Charles H. Ambler, and Nwando Achebe. Hoboken: Jon Wiley, 2019. 35-58. 
Miller, John. "The Glorious Revolution: 'Contract' and 'Abdication' Reconsidered." The Historical Journal 25.3 (1982): 541-555.

Mintz, Sidney W. Sweetness and Power: The Place of Sugar in Modern History. New York: Penguin, 1986.

Morrissey, Lee. “Transplanting English Plantations in Aphra Behn's Oroonoko.” Global South 10.2 (2016): 11-26.

Newton, John. Thoughts Upon the African Slave Trade. By John Newton, Rector of St. Mary Woolnoth. London: Printed for J. Buckland, in Pater-Noster-Row; J. Johnson, in St. Paul's Church-Yard; and J. Phillips, in George-Yard, [1788].

Nicolazzo, Sal. "Another 1987, or Whiteness and Eighteenth-Century Studies." Eighteenth-Century Fiction 33.2 (2020): 233-248.

OED. Oxford English Dictionary. Oxford University Press, 2021. Accessed online, 26 June 2021. «http://www.oed. com/>.

Osgood, Josiah. "Caesar and the Pirates: Or How to Make (and Break) an Ancient Life." Greece \& Rome 57.2 (2010): 319-336.

Pacheco, Anita. "Royalism and Honor in Aphra Behn's Oroonoko." Studies in English Literature, 1500-1900 34.3 (1994): 491-506.

Page, Melvin E. and Penny M. Sonnenburg. Colonialism: An International, Social, Cultural, and Political Encyclopedia. Santa Barbara: ABC-CLIO, 2003.

Patterson, Orlando. Slavery and Social Death: A Comparative Study. Cambridge: Harvard University Press, 1982.

Patterson, Orlando. The Sociology of Slavery: An Analysis of the Origins, Development and Structure of Negro Slave Society in Jamaica. London: MacGibbon \& Kee, 1967.

Polk, Khary. "Reviving Oroonoko." The Journal of Negro History 85.3 (2000): 154161.

Postma, Johannes. The Atlantic Slave Trade. Gainesville: University Press of Florida, 2003.

Ricoeur, Paul. Vom Text zur Person: Hermeneutische Aufsätze (1970-1999). Trans. Peter Welsen. Ed. Peter Welsen. Hamburg: Felix Meiner Verlag, 2005.

Ricoeur, Paul. Time and Narrative. Temps et récit. Trans. Kathleen Mclaughlin and David Pellauer. Vol. 1. 3 Vols. Chicago: University of Chicago Press, 1984.

Ricoeur, Paul. Time and Narrative. Temps et récit. Trans. Kathleen Mclaughlin and David Pellauer. Vol. 3. 3 Vols. Chicago: University of Chicago Press, 1988. 
Ricoeur, Paul. Time and Narrative. Temps et récit. Trans. Kathleen Blamey and David Pellauer. 3 Vols. Chicago: University of Chicago Press, 1984, 1985, 1988.

Robbins, Bruce. "Chomsky's Golden Rule: Comparison and Cosmopolitanism." Comparison: Theories, Approaches, Uses. Ed. Rita Felski and Susan Stanford Friedman. Baltimore: Johns Hopkins University Press, 2013. 191209.

Sass, Hartmut von. "Incomparability: A Tentative Guide for the Perplexed." Practices of Comparing: Towards a New Understanding of a Fundamental Human Practice. Ed. Angelika Epple, Walter Erhart, and Johannes Grave. Bielefeld: Bielefeld University Press, 2020. 87-109.

Schabert, Ina. Englische Literaturgeschichte: Eine neue Darstellung aus der Sicht der Geschlechterforschung. Stuttgart: Kröner, 1997.

Schneider, Ralf. "The Cognitive Theory of Character Reception: An Updated Proposal." Anglistik 24 (2013): 117-134.

Sedgwick, Eve Kosofsky. "Paranoid Reading and Repetitive Reading." Touching Feeling: Affect, Pedagogy, Performativity. Ed. Eve Kosofsky Sedgwick et. al. Durham: Duke University Press, 2002. 123-151.

Spengemann, William C. "The Earliest American Novel: Aphra Behn's Oroonoko." Nineteenth-Century Fiction 38.4 (1984): 384-414.

Sussman, Charlotte. "The Other Problem with Women: Reproduction and Slave Culture in Aphra Behn's 'Oroonoko'." Rereading Aphra Behn: History, Theory, and Criticism. Ed. Heidi Hunter. Charlottesville: University of Virginia Press, 1993. 212-233.

Watt, Ian. The Rise of the Novel: Studies in Defoe, Richardson and Fielding. London: Chatto \& Windus, 1957.

Wilks, Ivor. Forests of Gold: Essays on the Akan and the Kingdom of Asante. Athens: Ohio University Press, 1993. 